\title{
FINANCIAL REGULATIONS AND RISK IN THE CONTEXT OF THE GLOBAL RECESSION
}

DOI: 10.17261/Pressacademia.2020.1313

JBEF- V.9-ISS.4-2020(4)-p.320-335

\section{Serkan Sengul}

Yıldız Technical University, Department of Economics, Istanbul, Turkey. sengulserkan77@gmail.com, ORCID: 0000-0001-9891-9477

Date Received: October 10, 2020

Date Accepted: December 5, 2020

To cite this document

Sengul, S. (2020). Financial regulations and risk in the context of the global recession. Journal of Business, Economics and Finance (JBEF), V.9(4), p.320-335.

Permanent link to this document: http://doi.org/10.17261/Pressacademia.2020.1313

Copyright: Published by PressAcademia and limited licensed re-use rights only.

\begin{abstract}
Purpose- The purpose of this paper is to examine the effects of regulations on the risk during the 2008 financial crisis. In other words, , the causes of the 2008 financial crisis are presented and the main reforms made in the field of international banking after the financial crisis and their effects are offered.

Methodology- This study is a comparative situation analysis by using the data of Germany, United Kingdom, United States, EU Area and World. Findings- In order to cope with the effects of the crisis, the United States, Europe and other major economies, which constitute the basis of international financial architecture, have started to take measures rapidly. Priority has been given to eliminating the effects of the crisis on financial markets, and measures have been taken to create a new and strong financial architecture and restore financial stability. This study analyzes these measures and their effects on the economy.

Conclusion- After extensive arrangements, the banking sector recorded a significant increase in the amount and quality of capital. This success was mostly achieved with capital increases. The same positive situation is true for liquidity. This is seen not only in the improvement of the main liquidity ratios but also in the reduction of the simple ratio between loans and deposits. The obligation to provide bail for the liabilities of banks reduces the possibility that the banks will be supported by the government through bail in a future crisis.
\end{abstract}

Key words: Global recession, financial regulations, financial risk, financial markets JEL Codes: G01, G21, G18

\section{INTRODUCTION}

The 2008 financial crisis was a great experience for the banking sector globally. The sector has become more cautious by introducing models on important issues such as excessive risk taking, insufficient capital and liquidity buffers in industry (Cull, Martínez-Pería 2013). Regulators responded to the crisis with more capital, standardization in liquidity, stronger supervision and more specific solutions. Along with the changes in the globalization tendency of the real economy, due to the weak economic growth and low interest rates in most developed economies, the working area of the banks has changed significantly. Technology has found external powers, while banks' stakeholder scrutiny has increased. Thus, competitive pressure began to emerge in the market.

Costs of the financial crisis were huge. The International Monetary Fund (2009) states that covering the results of the global financial crisis has costed 11.9 trillion dollars in total (Merrouche, Nier, 2010, 4). Consequently, a relatively new research conducted by Atkinson et al. (2013) demonstrates a cost equivalent to 14 trillion dollars for the USA only after considering the amounts regarding the production, richness, the effects caused by national trauma and exceptional precautions taken by government (Choi, 2013, 362). Sanders explains that the Congressional Budget Office (CBO) made an estimation in January 2012, which shows the cumulative difference between the real GDP and presumed potential GDP after the crisis would cost $\$ 5.7$ trillion towards 2018 (Sanders, 2013, 16). 
According to Cull and Martinez-Peria (2013) immediately after the crisis, the banks began to respond to the financial crisis and the post-crisis market environment. In this context, banks went globally to reorganize and evaluate their growth plans, balance sheet positions, cost principles, organizational structures, scope of operations and geographical presence.

Risk is a fact that is inherent in the life of the financial sector as particular. The business world often grows by taking risks, and the greater the risk, the higher the profit naturally. Therefore, the business world needs to take risks for growth. Lessons are learned from past financial crises and new ways are opened for banks. However, this situation brings new risks. Banks should take these risks and take measures to overcome them.

In addition to this, Shaikh (2011) mentioned that an innate irresolvable conflict exists between capitalism's predisposition to discharge finance and its requirement to control the following instabilities. This innate conflict emerges in the regulation debate starting among unorthodox economics after the beginning of the late worldwide crisis. The 2007-2008 crisis has correctly been labeled as the very first major depression of the millennium. According to Sing (2011) there are three main risk categories: credit risk, market risk and operational risk. The techniques and tools necessary to manage these risks are discussed in detail.

A significant characteristic of the neoliberal reconstructing policies was nonintervention and freed internationalization of finance. This functioned to be preventing tendency towards the decreasing profit rate. Additionally, with the expanded labor exploitation, it gave way to reestablishment of the profit rate for duration of time. Yet, usage of finance to handle the problems resulted by capital accumulation while ignoring the essential reasons (emerging from the sphere of production) included important costs. It caused an increasing distance between finance and real accumulation. According to Mavroudeas and Papadatos (2012), hence, the financial increase in 2018 caused the emergence of the long-coming very first major depression of the millennium.

This study examines the effects of regulations on the risk during the 2008 financial crisis. In order to cope with the effects of the crisis, the United States, Europe and other major economies, which constitute e basis of international financial architecture, have started to take measures rapidly. Priority has been given to eliminating the effects of the crisis on financial markets, and measures have been taken to create a new and strong financial architecture and restore financial stability. In addition to the measures taken to combat the crisis, it is important to be able to foresee and prevent future crises before they occur.

In this context, the first part of the study examines the preliminary and comprehensive regulations that emerged at the beginning of the subprime mortgage crisis. The first of these frameworks is the adoption of a shift into a macro prudential policy approach. Dodd Frank and Basel III, which aim to manage financial institutions within the framework of more effective regulation and have a stronger capital and liquidity structure, are also examined under the chapter.

Since those initial responses to the financial crisis include number of target areas in financial system to adopt more resilient regulation frameworks, the second part of this study aims to evaluate the pillars of regulatory efforts under four headings. In the second chapter, the four pillars of the regulation against risk examined in terms of building resilient financial institutions, ending Too-Big-To-Fail (TBTF) issue, making derivatives markets safer and transforming shadow banking into resilient market-based finance. The first section of this chapter analyzes the changes in risk parameters before, during and after the crisis for given economies in order to evaluate the effects of regulations over risk parameters of financial system.

\section{REGULATIONS DURING CRISIS}

\subsection{The Initial Responses to the 2008 Financial Crisis}

Significantly dramatic events took place during the period of 2007-2008, such collapse of asset values, drying up of the liquidity and freezing of the credit markets, that interbank lending markets stopped, that some financial institutions crashed and many more of them called for public economical support of different descriptions to be able to trade (Claessens, Kodres, 2014, 7).

The pressure and imperative were constantly demanding for an action to be taken as fast as possible. Noticeably, forging a link between financial distress' symptoms, broken banking systems and freezing interbank markets to the destabilizing the financial market's congenital dynamics and the fall of current methods to regulate finance appealed to a great degree. Contrarily, Baker (2015) explained that associating the crisis to macroeconomic causes by underlying world-wide instabilities, the borders of limited take on inflation, the massive injustice and/or malfunctioning increase model are a lot more complicated intellectual ideas which need specifying a longer and detailed random link and a less urgent emotional mass appeal.

Evaluating the merits and demerits of these different reactions (a possible way to deal with the upcoming crises) and unraveling the lasting damages to the financial system are significant momentary duties. Meanwhile, Siron (2018) demonstrated that worldwide financial crisis has an important effect on the consideration of the ideal way to regulate finance, as well. Furthermore, Davis 
(2009) states that the world-wide financial crisis, in others' opinion, mirrors mainly the unsuccessful attempts to regulate and implement it, which indicates a demand for much better - yet not bigger - options to implement and regulate. Those who are in the same opinion of both views would possibly be in agreement with the fact that regulating finance withstands a much harder assignment in the area of financial innovation, in which advanced financial products and approaches are set up in at a rapid speed to negotiate regulations that disallows profit opportunities and under-supported regulatory agencies are, on a regular basis, try to play 'catchup' while handling those improvements (Beck et all., 2016, 29). As Davis explains (2009), they would most probably acknowledge that governance, incentive arrangements and the ways risk is managed have not been the best possible options and are in need of reformation.

Deregulation was perceived to mirror an increasing sense of security about risks, which as the increase of adequate markets, was another reason for regulatory failure. Stöhr (2015) made a declaration that as a result of decades without experiencing an extensive crisis, it is far too easy to dream that they have built a structure that is impenetrable against risks. Regulators must have forgotten that almost all of the regulation was to prevent the increase of speculative bubbles or signs of overconfidence and overjoy. Thus, Shiller (2010) pointed out that the indirect impacts of the adequate markets theory were meant that regulators should concentrate on hindrance of micro- mismanagement, as though it were not possible for anything to be wrong with the whole market.

During the financial crisis, a new approach to market regulation appeared and shaped by three significant phenomena. In the following section these three phenomena - a shift into a macroprudential policy framework the Dodd-Frank Wall Street Reform and implementation of Basel III standards will be evaluated with regard to their impacts on new wave financial regulation perspective.

\subsection{A Shift into a Macro Prudential Policy Framework}

The late financial chaos has caught the public and governmental attention from a market regulation, which is about a neoclassical, market-centered, self-regulating and a sort of laissez-faire style, to a much more state-based idea of compulsory legal rules that limit the leeway usually given to the market participants (Rubio, Carrasco-Gallego, 2016: 7). As reported by Seibt and Schwarz (2011), this generally agreed change of mind is most likely owing to (1) the dramatic losses in finance that have been made in the financial industry, and, furthermore, influenced the 'real' economy causing costs to be burden for the all society (social costs), (2) the astounding demand and shortage of another option that national state feel to save the financial intuitions of systemic relevance (i.e. some type of 'blackmail situation'), in addition to (3) the lack of confidence in the ethical behavior that all financial market participants do feel.

Following the crisis, differentiating further between supervising the individual financial firms in the micro-prudential level and guiding the systemic risks to the whole financial system (macro-prudential regulation). Gilad (2015) expressed that the idea behind the basic difference between these three functions - micro-prudential, macro-prudential and business-conduct regulation - is provide each task with an adequate thought. On the contrary, the goal of a strengthened regulatory structure is to aid regulatory consistency, collaboration, and information exchange.

The limited consideration of prudential regulation structured on capital requirements for banks fell short to hinder the big chaos towards the end of 2008. As United Nation report demonstrates (2016), of course, the subprime crisis and its results disabled a lot of the world's biggest banks which totally satisfied the Basel II standards in 2008, which caused government to create highly expensive bailout packages, leading the public debt and social costs to increase to a very importantly high degree.

Following 2009, the era during which affirmation of macroprudential policy scheme was included in different G20 communique's, there have emerged new policy committees for implementation of macroprudential policy in the USA (Financial Stability Oversight Council), the European Union (EU) (European Systemic Risk Board) and in the UK (FPC). Moreover, Glivanos (2014) inferred that the Basel III agreement took actions for countercyclical capital buffers, as a macroprudential policy instrument.

The macroprudential approach changes most of the assumptions regarding the efficient markets position as it denies that selfinterested investment strategies that are individually rational could provide financial stability and equilibrium by noticing the innate procyclical tendencies of finance, the tendency of investors for herd behavior and financial complexity's destabilizing impacts. Baker (2015) claimed that macroprudential policy includes benefiting from prudential cautions (a range of capital requirements, both fee-related and amount-related instruments) either to meet macroeconomic ends or to seek for protection of the actual economy against instability and financial excess. Additionally, Ennis (2009) described that these involve countercyclical capital demands, dynamic preparation for loan loss, demands of countercyclical liquidity, administrative limits on 
aggregate lending, reserve demands, caps on leverage regarding asset purchases, loan to income ratios, the lowest margins on secured lending, limits on currency mismatches, controls of capital and regulation of host country.

Krosner (2010) explained that micro prudential regulation, aimed to protect consumer, ought to apply every financial institution, particular attention challenged to protect unsophisticated, "vulnerable" in other words, consumers. Macroprudential regulation ought to be concentrated on main elements of systemic risk: the breakdown of big, inter-connected intuitions, leverage systematically significant behavior and instruments, and how they interact with the economic cycle. Furthermore, Lothian (2012) stated both macroprudential and micro prudential regulation ought to give specific consideration to possible risks the government undertakes via operating implicit or explicit deposit insurances. In addition, Gudumndsson (2015) said that macroprudential regulation has the goal of cutting down the finance's pro-cyclicality and its impacts on the actual economy. It achieves it through explicit incorporation of the macroeconomic variable's influences, which are exchange rate, interest rate movements and growth, on financial risk, particularly hindering the systemic risks accumulation and changing fundamental regulatory variables in a counter-cyclical style in order not to encourage lending booms and hindering credit crunches.

\subsection{The Reform of the Dodd-Frank Wall Street}

The second significant improvement that has been associated with the Dodd-Frank is the Dodd-Frank Act or Wall Street Reform. Although a lot of aspects caused the crisis and the possible effect of these aspects are questionable, the weaknesses and irregularities of the way the U.S. financial system is supervised and regulated made a significant contribution. To deal with such defects, the Reform of Dodd-Frank Wall Street and Consumer Protection Act (the Dodd-Frank Act) were enacted by Congress.

As the Senate Banking Committee's website summarizes, Schultz (2014) brought out that act aims to (1) deal with risks to the U.S. financial system's stability, partially by creating the Financial Stability Oversight Council (FSOC), (2) put a stop too-great-fall bailouts of big, complicated financial institutions, (3) expand transparency and regulation for particular complicated financial instruments, finally (4) intensify the ways consumers and investors are protected. Sanders (2013) said that the Dodd-Frank Act is going to be instrumental for the reduction of possibility or harshness of a future financial crisis. These preparations involve as it follows:

- Formation of FSOC (Financial Stability Oversight Council) and OFR (Office of Financial Research).

- Increased prudential standards for systemically signiant financial institutions (SIFI).

- Orderly Liquidation Authority.

- Swamps regulation.

- Reforms in mortgage-related and other areas.

The rules of US Dodd-Frank competition are particularly focused on the swamp market. Europe's Markets in Financial Instruments Directive (MiFID II) and suggested enforcing regulations are more earnest in capacity than reforms of the U.S. However, they are operated in a much slower way. Duffie (2016) said that enforcement of the most significant rules of trade-competition has been sent back to the beginning of 2018 .

\section{ENFORCEMENT OF BASEL III STANDARDS}

In November 2020, these capital reforms, along with the emergence of two international liquidity standards, reacted to the essence of world-wide financial reform agenda, which was presented to the Seoul G20 Leaders summit. The Committee, following the early comprehensive quantitative influence study that was published in December 2020, keeps on guiding and assessing the influence of these leverage, capital and liquidity requirements (abbreviated as "Basel III") semi-yearly (BIS, 2011). The third part of the Basel Accords was progressed as an answer to the defects of financial regulation illustrated by the 2007-2008 financial crisis. The aim of Basel III is to support requirements of bank capital by reducing bank leverage and expanding bank liquidity (BIS, 2017).

The first demand is about the capital. Further, the rule of Basel III called banks for self-funding themselves with $4.5 \%$ of common equity, which was $2 \%$ higher than Basel II, of risk-weighted advantages (RWAs). The research by Hessou and Lai shows that a minimum Common Equity TIER 1 (CET1) ratio of 4.5\% always have to be provided by the bank since 2015. The minimum Tier 1 capital expands from $4 \%$ to $6 \%$, appropriate to 2015 , over RWAs. The $6 \%$ is made up of $4.5 \%$ of CET1, as well as an additional $1.5 \%$ of Additional Tier 1 (AT1). 
What is more, Basel III brought two more capital buffers (BIS, 2017):

- A compulsory "capital conservation buffer", which is equal to $2.5 \%$ of risk-weighted advantages. Taking into account the 4.5\% CET1 demanded by capital radio, starting in 2019, banks have to have a total of 7 percent CET1 capital ratio.

- A "discretionary counter-cyclical buffer", which makes it possible for national regulators to ask for up to an extra $2.5 \%$ of capital in times of increase of high credit. The amount of this buffer changes from $0 \%$ to $2.5 \%$ of RWA and have to be satisfied by CET1 capital.

As argued by Teixeira et al (2014), another demand is related to ratio of minimum leverage that is a risk-free grounded leverage ratio and its calculation is performed with division of Tier 1 capital by the bank' average total consolidated advantages ( total of the exposures of all advantages and sheet items that are not balanced). Just as the Bank for International Settlement exposed, its definition is "the capital measure over exposure measure". Whereas Tier 1 is the capital measure, accounting values (the total of on-balance sheet exposures, derivative exposures, non-balance sheet exposures and transaction exposures financed by securities) make up the exposure measure. It is expected from banks to provide a leverage more than 3 percent as ruled by Basel III. The U.S. Federal Reserve made an announcement in July 2013 that the minimum Basel III leverage ratio was going to be 6 percent for 8 systemically important financial institution (SIFI) banks and for their secured companies that hold bank.

The last one is related to the liquidity ratios that are divided into two groups. The "Liquidity Coverage Ratio" was expected to demand a bank to have adequate high-quality liquid advantages to compensate its total cash discharges during 30 days. Rubio and Carrasco-Gallego (2016) stated that it was expected from "The Net Stable Funding Ratio" to demand the accessible sum of stable funding to go beyond the demanded sum of stable during a one-year duration of extended stress.

\section{THE CAUSES OF THE FINANCIAL CRISIS AND REGULATION AGAINST RISK}

The crisis that occurred in 2007 is one of the biggest crises of recent years. The occurrence and causes of this crisis has caused new concerns to be raised by policy makers, practitioners and academics. According to many researchers, the crisis started with the deterioration in the credit quality of high-interest housing mortgages, especially those with adjustable interest rates. After this deterioration, specialized mortgage companies experienced fund pressures and many of them failed.

One of the most crucial causes leading to the financial crisis was the instant expansion of wealth in a lot of countries throughout the World. A few years prior to crisis, a huge upsurge in the number of advantages accessible to invents for those who seek for both profitable and safe returns. In this chapter, the reasons that caused the crisis and the precautions to avoid these reasons will be considered.

\subsection{Shadow Banking and Dodd-Frank Act}

Financial entities that borrow short-term and lend long-term are called shadow banking. However, unlike traditional banks, they are not covered by the banking regulations. Therefore, the shadow banking system has had more impact on the outbreak of the 2008 crisis compared to the traditional banking system. So, the shock caused by the burst of the housing bubble and the major crisis has more affected shadow banking than the traditional banking system.

Regulations on bank capital have always been the subject of debate by politicians and researchers (Admati, Hellwig, 2014). In addition to these challenges, regulators had to deal with the encounters that emerged after the 2008 financial crisis. As an example, Angeloni and Faia (2013) inserted that systematic banking crises can be prevented and concerns about financial crises need to be taken into consideration when preparing bank capital requirements. Moreover, the emergence of financial intermediaries other than the traditional banking sector, also known as shadow banks, causes problems such as legal arbitrage in the regulations regarding traditional banks. This situation identifies a very important problem. Because, financial instability during the 2008 financial crisis, shadow banking has led to a large extent.

Friedman and Kraus (2011) explained that shadow banking system is made of financial entities beside thrifts and commercial banks. Mortgage specialists, off-balance sheet entities, along with structured investment vehicles (SIVs) as well as conduits for advantage-backed commercial paper ( $\mathrm{ABCP}$ ); and investments banks that are free-standing (independent from commercial banks), Goldman Sachs, Bear Stearns, Morgan Stanley, Lehmen Brothers and Merrill Lynch for instance, and the BHCs' investmentbank arms like Citigroup are also included. Kim et al (2012), meanwhile, investigated that the shadow banking system, believed 
to took a crucial part in the late crisis, is made up of investment banks, hedge funds and VC/PE ${ }^{1}$. Even though shadow-banking system might increase the possibility of risk and vulnerabilities, it is also functional to give benefit of varied funding to the actual economy. The greatest success in the field of shadow-banking is the advanced set of codes to govern money market mutual funds. The type of the constant-net-asset-value's (CNAV) money fund could sometimes be limited to a fixed value, in spite of fluctuations happening in time in the actual market of value of their advantages. Duffie (2016) illustrated that a lot of those who invest, consequently, took CNAV funds for bank deposits, hence subject to a run whenever the redeemed value of the funds could decrease. It is absolutely what occurred on a big scale in the U.S the moment Lehman Brothers fell short.

Money Market Funds (MMFs), the part of the shadow-banking sector in question, are reciprocal funds that are most of the time invested in the short-time debts banks, (local governments) and/or corporations. The tools in which the funds invest consist of commercial loans, government treasury bills or certificates of deposit as explained by Finance-Watch (2017). Shadow banking is characterized as one of the factors leading to the 2007-2008 financial crisis, while at the same time causing the financial sector to grow further. The risks of shadow banking arise from the lack of control and check systems in the sector. In Germany, mutual funds rose to 58.2 percent in 2015 from 37.2 percent of GDP in 2008. Similarly, in the UK it increased from 28.6 percent to 44.6 percent, in the euro area from 10.7 percent to 19.8 percent, in the United States from 82.5 percent to 99.2 percent respective to GDP (Figure 1).

\section{Figure 1: Mutual Fund Assets to GDP}

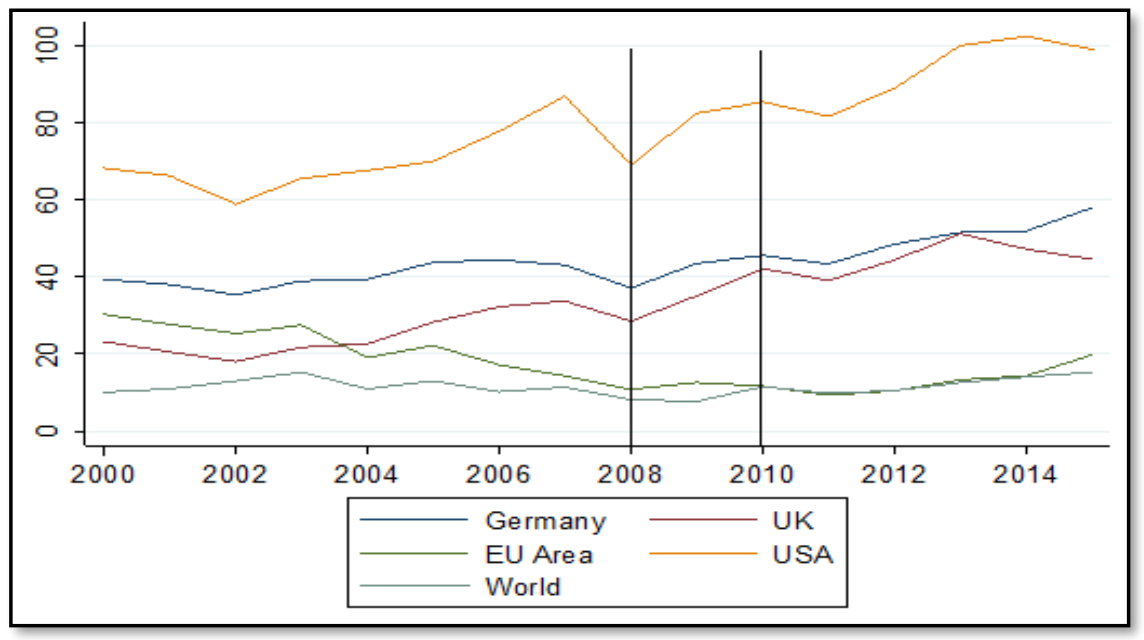

Source: World Bank. 2018. Mutual Fund Assets (\% Of GDP).

The international reform agenda under FSB (Financial Stability Board) tutelage executed a few initiatives, such as Dodd-Frank Act and suggestions to develop supervision of activities by shadow banking. Plus, G20 countries came to an agreement to gradually include the new standards in their regulatory work grounds (United Nations, 2015: 89). Stated by Dodd Frank, in case of improvement in market discipline, shorter discount for size on yield spreads, especially for banks associated as too-big-to fail (TBTF) or systemically significant (SIFI) can be inspected. In 2014, Balasubramnian and Cyree explained that commission that used secondary market subordinated dept transactions, discovered that size discount is lowered to 47 percent and TBTF discount is lowered to 94 percent, following the DFA. The DFA has influenced the reducing, while has not taken part in the elimination of size and TBTF discounts on yield spreads. It is observed that banks' market discipline has been improved further, following the changes in rating criteria by Moody's.

Kroszner (2010) said the Dodd-Frank Act builds a contemporary work frame that highly promoted the movement of OTC derivatives to platforms cleansed in the center and expands disclosure and exposures. It also maintains a new work frame to regulate, observe and govern the clearinghouses. Powerful incentives via differential capital charges for centrally cleared vs OTC

\footnotetext{
${ }^{1}$ Venture capital and private equity (VC/PE), providing new-comer companies with support of capital and managements, are gradually though as the new kind of instution in the field of finance.
} 
derivatives might be appointed to the big players in derivatives markets in order to transfer the current contracts, to the most possible degree, to other platforms and create contracts with adequate standardization that is possible to cleanse in the center.

The financial crisis has fully demonstrated how shadow banking adversely affects the financial system. Consequently, the DoddFrank Wall Street Reform and Consumer Protection Act established the Financial Stability Oversight Council and the Financial Research Office to assess emerging risks and monitor the shadow banking system.

\subsection{Bank Capital and Basel III Standards}

This section analyses the changes of bank capital structure before, during and after the crisis through bank regulatory capital to risk-weighted assets, bank capital to total assets and measures taken within this framework.

Risk weighted assets is an important measure method at both macro and micro level (Lesle, Avramova, 2012). According to the study of these researchers, risk weights assets have three important functions for banks. (1) Provide a common measure for the risks of the bank; (2) ensure that capital is proportionate to risks, (3) potentially emphasizes where instability entity class bubbles occur. According to the study of Berger and Bouwman (2013), two main results emerge. First, capital always helps small banks (including periods of crisis) to survive and increase their market share. Second, capital helps medium and large banks, particularly those with limited government intervention during banking crises.

The aim of the Basel III2 criteria established after the 2008 crisis is to increase the flexibility of the banking and to promote financial stability against unexpected shocks. The most important purpose of Basel III standards is higher and better quality capital. Sanders (2013) explained that one regulator detected the leverage ratio as well as the higher demands of common equity and tier 1 capital required within standards of the Basel III, reflects an important fastening of capital regulation combined with capital's better quality and a few higher risk weights imposition. Further, Cohen (2013) discovered that a lot of national authorities have had publications of figures on bank capital sufficiency. They do not make use of the shared definitions either the numerator, which is capital, or denomitator, which is assets, though. They have the tendency to approve a picture that reflects rise of capital ratios in the world-wide banking system.

Regulatory capital to risk weighted assets ratios for large, internationally active banks in world rose from $14.5 \%$ at the end of 2008 to $17 \%$ at the end of 2018 while banks in Euro area from $11.6 \%$ to 18.3 percent. Even though the figures showing riskweighted capital ratios are not suitable for a full comparison for the chosen countries because of particular banking legislations, differences in the example banks, quality of data and several relevant descriptions, the guidance and the size of the real expansion is possible to have been generally in league with the results descripted as it follows (Figure 2).

\section{Figure 2: Bank Regulatory Capital to Risk-Weighted Assets}

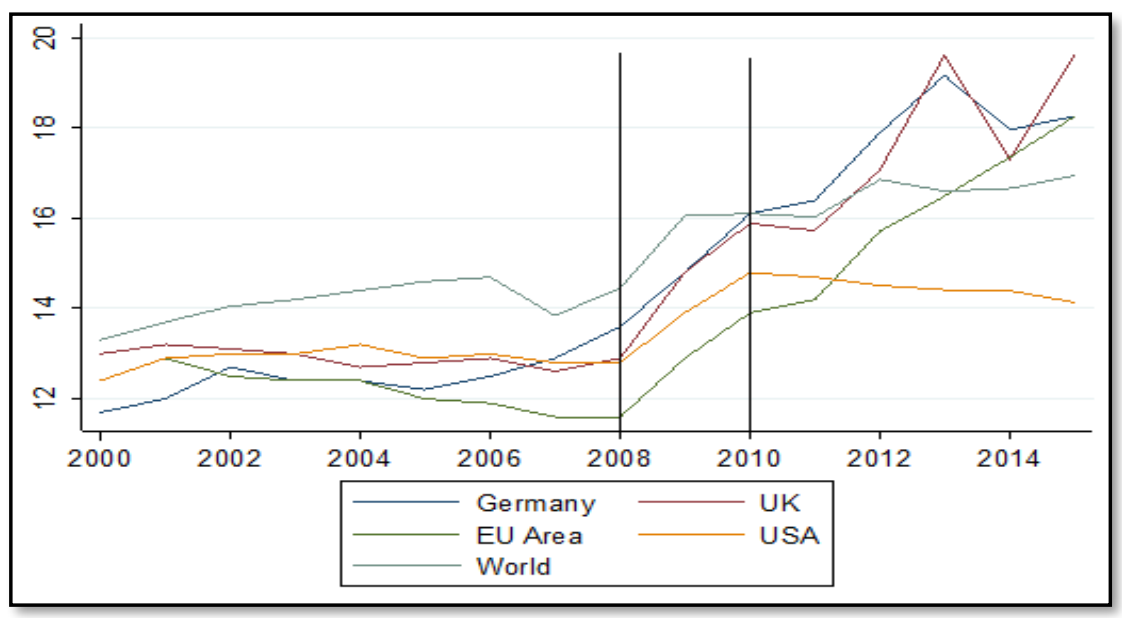

Source: World Bank. 2018. Bank Regulatory Capital to Risk-Weighted Assets

\footnotetext{
${ }^{2}$ Basel III is an internationally consented set of precautions created by the Basel Committee on Banking Supervision in as a reaction to the financial crisis of 2007-09. The precautions have the goal of strengthening the regulation, supervising and managing risks of banks.
} 
The more the assets of regulatory capital banks, the more resistant they are to the negative shocks. However, due to differences between countries in policy and accounting, it is not healthy to compare data with countries. When analyzing European Union Area, towards the beginning of 2011, it is observed that EU-centered banks possessed a Tier 1 capital ratio of 10.42 percent, a big increase when it is compared to 2007 , when Tier 1 capital ratio was estimated as $7.7 \%$.

In the USA's case, The Federal Reserve structured its unchanged regulatory capital standards, partially, on Basel's perspective that is viewed as limited by many experts. It is acknowledged that Basel III standards take into account several of the limitations brought out by the financial crisis in the regulatory work frame, but provide that Basel III goes on placing a great amount of reliance on risk-grounded perspectives while detecting the capital sufficiency (Tian, 2017, 15). Therefore, during and after the crisis period, risk weighted assets to bank capital for US banks slightly reduced but still remained above the pre-crisis periods.

Following the world-wide financial crisis, tightening the capital ratios is a significant improvement in the field of banking. In league with this, the bank capital to total evaluates how much banks could possibly handle losses which is rated among the biggest functions of risk. The bank capital to total assets restrain banks' capacity to leverage up their sheets of balance and could be considered naturally countercyclical, particularly owing to the leverage procyclicality (Giordana, Schumacher, 2013, 635).

The capital ratio to total assets for US commercial banks increased from 9.30 percent to 11.7 percent from 2008 to 2015 . The Euro area monetary financial intuitions' ratio, evaluated on a consolidated period, rose to 7.5 percent from 5.9 during the same amount of time and date. However, being 10.3 percent, it is much lower than average of the world. Similarly, although there is a tendency to increase after the 2008 financial crisis, the capital to assets ratios of banks in UK and Germany are lower than the World and Euro zone averages (Figure 3).

\section{Figure 3: Bank Capital to Total Assets}

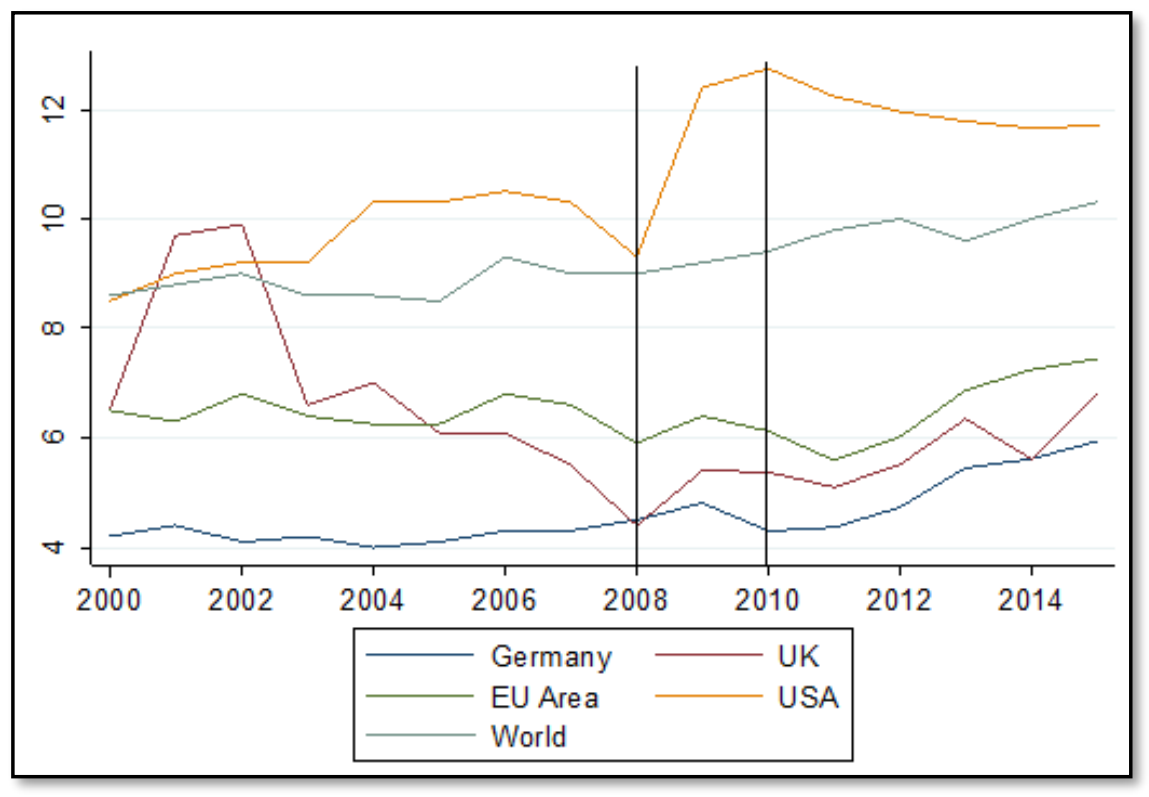

Source: World Bank. 2018. Bank Capital to Total Assets

During the crisis of 2007-2009, a few banks suffered from capital shortages, partially as they experienced big losses on assets which Basel's standard assigned low risk weights yet posed much bigger risk than risk weights. The Basel III scheme is going to expand risk weight for particular advantage classes - and consisting of a leverage ratio as a defense against irregular risk weights - but specialist notified that the possibility is sustained for financial institutions for "gaming" the Basel risk weights with expanding holdings of advantages that have risk-weights that are not greater than the actual risks. Additionally, in 2013, Quaglia expresses that some specialists sustain their idea that Basel standards generally could not give an adequate buffer for protection of firms in stressed times. This approach is embodied in the given table for each samples of economy during the crisis, however, the extended impact of regulations has started to shown their effects after the crisis period. 
Regulations on bank capital have always been the subject of debate by politicians and researchers (Admati, Hellwig, 2014). In addition to these challenges, regulators had to deal with the encounters that emerged after the 2008 financial crisis. As an example, Angeloni and Faia (2013) inserted that systematic banking crises can be prevented and concerns about financial crises need to be taken into consideration when preparing bank capital requirements.

\subsection{Bank Liquidity and Basel III Liquidity Standards}

The aim of this section is to explore the liquidity and crisis issues in the academic literature to understand the role of liquidity in the 2008 crisis. In 2007, problems started to occur in the interbank funding markets in USA, UK, Germany and other European countries. Therefore, banks, especially for long-term liquidities, have started to be reluctant to provide liquidity to other banks. In 2007, problems started to occur in the interbank funding markets in USA, UK, Germany and other European countries. Therefore, banks, especially for long-term liquidities, have started to be reluctant to provide liquidity to other banks. As a result, Libor rose significantly.

There are two obvious reasons for this liquidity-hoarding situation. On the one hand, banks need to protect themselves against greater potentials than expected, thus they need deriving from commercial paper markets, syndicated loans and disruptions in the mortgage. On the other hand, uncertainties increased as banks could not fully assess the exposure of their counterparties to securities of high interest and other interrupted markets.

In December 2010, the Basel Committee on Banking Supervision determined the introduction of liquidity standards for banks in addition to the measures taken in Basel II. In addition to the strengthened capital requirements, Basel III introduced a riskweighted leverage ratio to the markets to ensure adequate funding in crisis situations.

In addition, Basel III criteria developed two measures for liquidity crisis. The first is Liquidity Coverage Ratio, which aims to ensure that banks have sufficient liquid assets to withstand liquidity stress in the short term. The second is the Net Stable Fund Ratio, which aims to encourage banks to be more stable against their liquid assets and to hold long-term funding sources. These measures are aimed to reduce the risk of maturity conversion.

Basel III liquidity standards have undergone significant changes since their first issued in 2010. These changes include further differentiation to allow identification of banks with excessive maturity mismatches and more fragile funding structures (BCBS, 2014). These strategies are likely to affect the liquidity management function of banks if a stronger emphasis is placed on the retention of assets, particularly government securities. Allen et al. (2012) in their study discussed, especially the restructuring of banks' balance sheets for more liquid assets and as a result of the impact on the availability of the loan. Covas and Driscoll (2014) developed a balance to examine the macroeconomic impact of introducing a minimum liquidity standard on existing capital adequacy requirements for banks.

In the case of equilibrium, they have developed, the minimum liquidity requirement recommends a 3 percent decrease in loans and a 6 percent increase in securities. While this liquidity regulation prevents banks from using all their profits, the bank reduces the credit supply and increases the cost of funds. Despite the resulting costs, the main purpose of the new regulations is to ensure the stability of banks. According to Farag et al. (2013), although capital and liquidity sources are important for the security and soundness of banks, much is not known about newly established liquidity standards.

It was mentioned by Cerrato et al (2012) because it is an alternate standing for what sum of customer deposits and short term funding could be covered were they to be withdrawn instantly, Short Term Funding ratio and Liquid Assets to Deposits could possibly function as a deposit run off ratio. As the ratio gets greater, the bank becomes more liquid and and it becomes less vulnerable against a classic run on the bank.

In the era prior to crisis, domestic banks showed thicker capital cushions than global banks and stronger signs of structural liquidity. The liabilities of global bank are structured in a way more predominantly dependent on non-deposit funding and built as short-term (Vazquez, Federico, 2012, 11). However, during and after the crisis, the roles of short-term funding on risks are more significantly pointed out by regulating bodies. The world average ratio is 25 percent and the Euro area average is 28.7 percent by the end of 2015, both of which are lower than the values during the 2008 crisis (Figure 4). 
Figure 4: Liquid Assets to Deposits and Short Term Funding

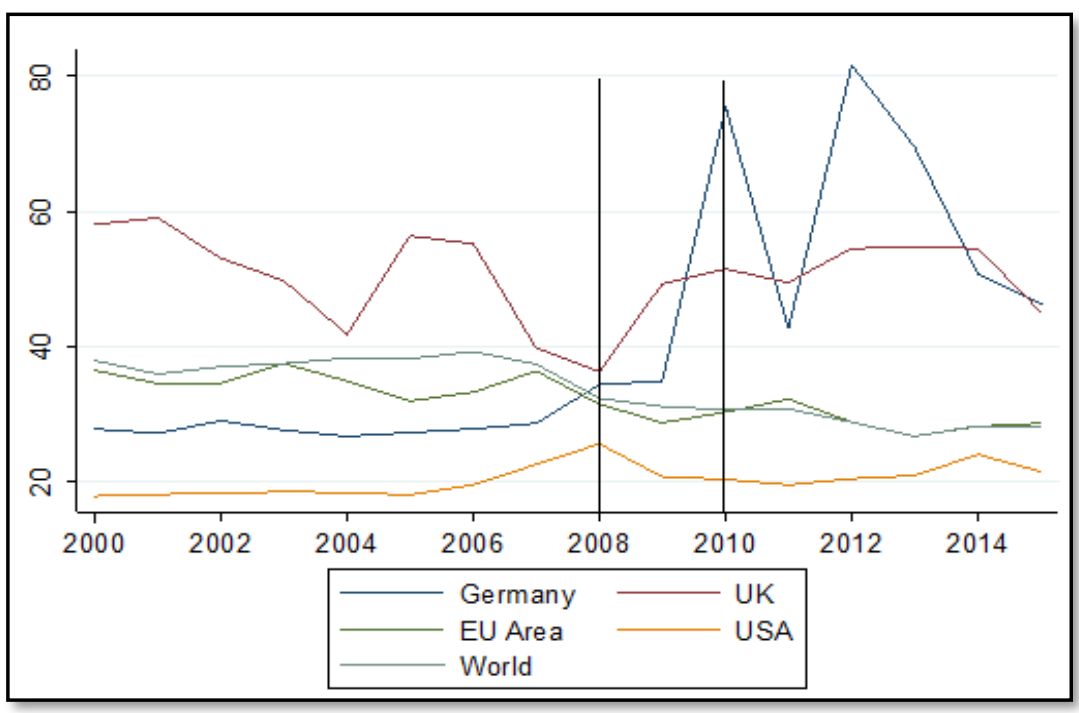

Source: World Bank. 2019. Liquid Assets to Deposits and Short Term Funding

When the Figure 4 is examined in detail, the rates of short-term debt borrowing by German and the UK banks are higher than the crisis period, above the world and Eurozone averages. The US banks, on the contrary, tend to fall short-term borrowing rates and move away from the world average. This can be linked with one of the major risk approaches of Dodd-Frank and Basel III applies to liquidity requirements of banks to mitigate risks.

On the other hand, Cihak et al. (2015) revealed that liquid liabilities are the total of central bank's deposits and currency, and electronic currency and deposits additionally (M1), also saving deposits and time, certificates of deposit, foreign currency transferable deposits, agreements on securities purchase, also checks for travelers, time deposits for foreign currency, commercial paper, and shares of common funds or residents' market funds.

\subsection{Bank Profitability and Z-Score}

As mentioned in the above sections, the financial crisis has a negative impact on the financial system and financial stability. In this context, profitability is affected by this process as well as by the bank's unique characteristics and macroeconomic conditions.

In the early stages of the financial crisis, many banks experienced problems due to the discrepancy in their funding of loans. For years, banks have been financing most of the long-term lending through short-term borrowing. Long-term low inflation and low interest rates led to a decline in profit margins for banks. This has affected the risk appetite in seeking higher returns.

In the course of the late financial crisis, the probability of bank has gained a strong attention from policymakers and regulators. Actually, research by Rossi et al (2018) shows that both capital expansions and strategies to self-finance - needed to maintain a bigger level of capitalization - depends on a bank's capacity to produce profits. Yet, the factors determining profitability of bank, which is observed to be certainly defined by preceding literature, seem to have undergone a change, affected by regulatory and competitive dynamics.

A lot of bank-specific variables that are accounting and/or marked give hints about the health of bank and evaluate its risk. The main alternative for a bank error risk is the z-score, which is the equivalent sum of the return on advantages (ROA) and the capital asset ratio separated by the standard deviation by ROA after Balasubramnian and Cyree $(2015,160)$. A well-known risk handling measure z-score was structured by Roy (1952) and improved by Graham (1986). Lacteacru in 2016 said that the major result of the measure z-score is a bank of low-risk is going to possess a big value of z-core, signing that a great number of basic deviations of a bank's advantage return must lower to be called insolvent. The opposite is a very low value of z-score suggests bigger risk for the bank. 
In 2007 , the credit ratings of securities were rated more than they should have. In this context, the Altman z-score showed that the risks of companies increase significantly and they tend to go bankrupt. Altman calculated the average $z$-score of the companies in 2007 as 1.81 . The credit ratings of these companies correspond to B. The fact that about half of the firms have low grades means that these firms are highly distressed and the probability of bankruptcy is high. Altman's calculations show that there will be a meltdown in the credit market and as a result there will be a crisis.

In the charts below, it is seen that in each of the sample economies, following the 2008 crisis, the bank z-scores were first severely declining, followed by a restoration process. Compared with the respective figures in 2008-2009 and 2015, the average of German banks' z-score rose from 8.75 to $21.6 \%$; as banks in the UK from 3.79 to 9.83 ; banks in Euro area from 8.31 to 10.31 ; US banks from 21.2 to 27.75 ; and the average of world banks from 10.9 to 11.2 (Figure 5).

\section{Figure 5: Bank Z-Score}

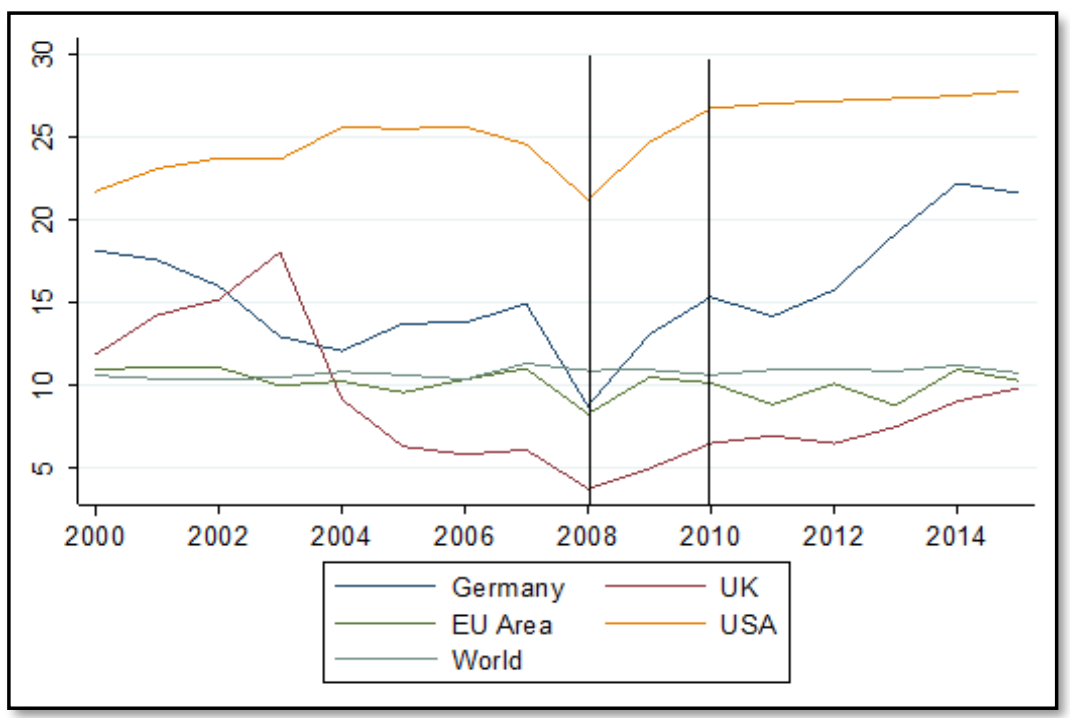

Source: World Bank. 2019. Bank Z-Score

The regulations of liquidity cause a shortening in average possibilities of error. It was found by Giordana and Schumacher (2017, 3 ) that the regulation of liquidity that concentrates on maturity mismatches cause a decrease to happen in average possibilities of error. Interchangeably, the influence on profitability of bank is less obvious, what appears to be significant is funding structure of bank, instead of the features of assets' portfolio. Likewise, it might be expected that greater ROA causes to decrease risk of default and that as it expands the possibility for equity to fall short of losses, the standard deviation on the return on assets decreases the z-score. Basically, the mutually adopted regulatory groundworks and the common monteray system such as DoddFrank and Basel have gradually supported these combinations in areas of Euro, the US and the UK.

Yet, contrasting results might be found out the moment ROA is considered along with the simultaneity of CAR. Strictly speaking, as explained by Giordana and Schumacher (2013), the leverage's level influences the ROA and the latter affects the former, which change the dynamics between its components and z-score. For instance, if a bank's ROA is developed by expanding its leverage, it is totally likely that the boost in ROA makes this bank closer to error. In this sense, macroprudential efforts in regulatory frameworks after the crisis aimed at improving the banking systems' ROA in order to increase its leverage and thus to drop overall risk of the system.

In our analysis of the sample countries, the figures of the normalized ROA for the five economies show a cyclical pattern especially between the period 2006 and 2014. In the case of Euro area, the UK and Germany, it appears that ROA is still lower than the precrisis period while the cyclical character of the industry replaces to a rather stable form. In the case of US banks, the recovery period for the US banks is still in progress while their counterparts in Germany, pursue a downwards trend since 2011. The ROA trends in world averages and Euro area showed a similar pattern. It is also seen that there is a similarity between these scales graphically, as the ROA is examined in accordance with the $z$-scores presented above. 


\subsection{Too Big to Fail (TBTF) and Living Wills as a Potential Solution}

Under Dodd-Frank, created after the 2008 financial crisis, the Financial Stability Oversight Council and Orderly Liquidation Authority supervise big major financial firms' financial stability whose fail could cause seriously negative effects on the economy of the U.S (firms labelled as "too big to fail"). Higher loss absorbency implementation, TLAC (Total Loss-Absorbing Capacity) and more thorough oversight is improving in a good level for worldwide systemically significant banks (G-SIBs). Meanwhile, as reported by Financial Stability Board (2017), advance has not been faster on other reforms regarding resolution for the past year and substantial work requires to structure influencing regimes of resolution and for operationalization of resolution plans for crossborder firms.

The main is the elimination of the too-big-to-fail approach and the moral hazard/excessive risk-taking movements elicited by it thanks forcing SIFIs to bigger capital demands and tightened prudential standards. The alleged "SIFI Project" was significant in the work plan recommendations of the FSB. Due to the apparent global significance of SIFIs with a big international existence, in Seoul, the G20 consented that FSB concentrates primarily on the "worldwide" systemically significant institutions of finance. The FSB had agreed on three interrelated ways to deal with prudential standards, oversight and resolution, respectively. Nolle (2012) stated that those criteria consist of leverage, size (considering on and off-balance sheet exposures and extension of credit), maturity mismatch and liquidity risk, interconnectedness, degree of current regulatory scruinty and lack of substitutes.

It is expressed in Dodd-Frank Act that should market discipline be bettered, shorter discount for size on yield spreads, especially for banks labelled as too-big-to-fail (TBTF) or systemically important (SIFI) is possible to be mirrored. Commission, which used secondary market subordinated transactions, discovered that whereas TBTF discount is lowered by 94 percent as a result of the DFA, the size discount falls down by 47 percent. The DFA has taken an influential part in lowering the size and TBTF discounts on yield spreads, while it did not affect their elimination. Balasubramnian (2014) persistently claim that the changes in the rating criteria by Moody's seem to improve the market discipline of banks.

The Dodd-Frank Act, implemented plans to solve the TBTF problems. According to Article 165 (d) of the Dodd-Frank Act, banks with assets above $\$ 50$ billion are required to submit annual resolution plans. This requirement includes banks as well as financial institutions designated by the Financial Stability Monitoring Council. This arrangement, commonly known as living will, develops detailed strategies to reach a solution while experiencing financial distress or failure. The act obliges all large-scale financial institutions to organize a "living will" to explain how to get out of this situation when they are in distress. An effective living will probably create favorable conditions for regular liquidation. Thus, it protects the banks from the danger in the first place and saves them time. Therefore, the reform should lead to lower TBTF subsidies, thus leading to higher capital costs.

In this context, Federal Reserve regulators may approve living will or refuse until the bank develops a sound strategy. Living wills provides a theoretical solution to TBTF, both by reducing systematic externalities and by increasing regulatory commitment. Therefore, from the beginning, regulators have issued specific instructions both to reduce the likelihood of living will in distress and to intensify systematic externalities. These efforts are first initiatives in order to call for bailouts. Furthermore, if these attempts as living wills can be seen as credible, then they come up to the time inconsistency problem which is confronted by the regulator by falling the possible agency costs which can be a cause a bank failure. Consequently, there might be a rise the bargaining power of the regulator in guiding financial distress of a bank because of the downward pressure on the hidden failure cost of uncertainty. There are also rising political costs to bailing out a bank because the regulator signalized publicly that it would not be so. Because of the cost of regulation, it is hard to believe banks differentiated considerable before execution. In addition, Acharya et al. (2016) state that since the TBTF firms are not listed explicitly, TBTF cannot apparently specify the treated group.

\section{DISCUSSIONS AND CONCLUSION}

In this study, the causes of the 2008 financial crisis are presented and the main reforms made in the field of international banking after the financial crisis and their effects are offered. In particular, the US government took immediate action to stabilize the financial system in the crisis. Emergency measures for the financial crisis have created an opportunity for new financial arrangements. In this sense, the Dodd-Frank Act has been the most comprehensive revision of financial regulation in the United States since the 1930s. The law stipulated mandatory regulations to improve transparency on certain issues. In this context, it authorized the Federal Reserve for surveillance. It also established the Consumer Financial Protection Bureau to reduce consumer benefit practices. These regulations significantly increased the capital requirements, increased the quality of the goods calculated as capital, and introduced new liquidity and leverage requirements. It also reduced the possibility that banks would use their own internal models to calculate their capital needs and increased the need for large banks to reduce losses. Furthermore, the DoddFrank Act, implemented plans to solve the TBTF problems. According to Dodd-Frank Act, banks with assets above $\$ 50$ billion are 
required to submit annual resolution plans. This requirement includes banks as well as financial institutions designated by the Financial Stability Monitoring Council. This arrangement, commonly known as living will, develops detailed strategies to reach a solution while experiencing financial distress or failure. The act obliges all large-scale financial institutions to organize a "living will" to explain how to get out of this situation when they are in distress.

As mentioned in the above section, Dodd Frank and Basel III, which aim to manage financial institutions within the framework of more effective regulation and have a stronger capital and liquidity structure, are also examined. Therefore, important efforts under Basel III are also important in order to move away from the effects of the crisis and make new arrangements. Basel III criteria are applicable to all financial institutions in the world. The USA, Europe and many other countries have changed their laws according to Basel III. This is an important step towards financial crises. Basel III has tried to acknowledge pro-cyclicality via measures, whose goal is to maintain stability during the course of time. These consist of counter cyclical capital fees and provisions that are forward-looking, rules of capital protection for powerful capital buffers, systematic-based financial institutions and their systemic capital charges. Dodd-Frank Wall Street Reform and implementation of Basel III standards evaluated regarding their impacts on new wave financial regulation perspective.

Another important regulation is living will. Recently, aftermath of the financial crisis in 2008, regulators are globally calling for alleged living will. It is an incident scheme for financial institutions such as banks that is shelf-depending if the asset should be resulted in bankruptcy, closing, selling or shattering. At first glance, banks may see living will as regulations made by external force to the living will requirements. Banks and other financial institutions are affected by these regulations, however, if they look at compliance requirements and develop more strategic plans, they will get real benefits. One of the frequently discussed aspects of such a plan is that it can be used to simplify institutional structures. If so, restructure financial institutions that will facilitate their profitability to reduce their financial strength.

Too big to fall is a vital to an economy that it would be disastrous if they went bankrupt. Therefore, urgent arrangements had to be made on this issue. Too big to fall practices reflect the government's perception that large financial firms serve the public good. This situation necessitated a legal regulation. In this context, the Dodd-Frank Wall Street Reform and Consumer Protection Act have introduced practices to eliminate too big to fall practices. The main ones were to prevent excessive financial companies from taking excessive risks and to increase regulation and audits.

After extensive arrangements, the banking sector recorded a significant increase in the amount and quality of capital. This success was mostly achieved with capital increases. In the latest report of the International Monetary Fund (2017), it was shown that the 30 largest banks in the world obtained capital of approximately 1 trillion dollars from 2009 to 2016 . As a result, the average ratio between capital and total assets increased from $5 \%$ to $7 \%$. Great success has been achieved in these practices.

The same positive situation is true for liquidity. This is seen not only in the improvement of the main liquidity ratios (see figure 5) but also in the reduction of the simple ratio between loans and deposits. In the sample of the 30 largest banks mentioned above, this ratio decreased from $90 \%$ to $75 \%$ from 2006 to 2016 . Increases in the amount of bank capital and liquidity have reduced the likelihood of large banks defaulting and taking greater risks in the future. In addition, the obligation to provide bail for the liabilities of banks reduces the possibility that the banks will be supported by the government through bail in a future crisis.

\section{REFERENCES}

Allen, B., Chan K.K., Milne, A. Thomas, T., (2012). Basel II: Is the cure worse than the disease? International Review of Financial Analysis, 25, 159 -166 .

Acharya, V. V., D. Anginer, and A. J. Warburton, (2016). The end of market discipline? investor expectations of implicit government guarantees. Available at SSRN: $\quad$ https://ssrn.com/abstract=1961656 or http://dx.doi.org/10.2139/ssrn.1961656

Atkinson, T., Lutterell, D. and Rosenblum, H. (2013). How bad was it? The costs and consequences of the 2007-09 financial crisis, Staff Papers, No. 20, Federal Reserve Bank of Dallas, Dallas.

Baker, A. (2015). Varieties of Economic Crisis, Varieties of Ideational Change: How and Why Financial Regulation and Macroeconomic Policy Differ, New Political Economy, 20:3, 342-366.

Balasubramnian, B. and Cyree, K.B. (2014). Has market discipline on banks improved after the Dodd-Frank Act?, Journal of Banking \& Finance, Vol. 41, 155-166.

Basel Committee on Banking Supervision (BCBS). (2014). Basel III: The Net Stable Funding Ratio, October.

Beck, T., Chen, T. and Song, F. (2016). Financial Innovation: The Bright and the Dark Sides, Journal of Banking \& Finance, Vol. 72 , issue C, $28-51$. 
Berger, A.N. and Bouwman, C.H.S. (2013). How does capital affect bank performance during financial crises?, Journal of Financial Economics, Vol. 109, 146-176.

Berube, G. (2013). Basel III and pension funds: What lies ahead, http://www.benefitscanada.com/pensions/db/basel-iii-and-pension-fundswhat-lies-ahead-36852 (10.08.2017).

BIS. (2011). Basel III: A global regulatory framework for more resilient banks and banking systems, Bank for International Settlements (BIS), Basel. Available from: http://www.bis.org/publ/bcbs189.pdf (10.08.2017).

BIS. (2011). Basel III Monitoring Report, Bank for International Settlements (BIS), February, Basel. Available from: http://www.bis.org/bcbs/publ/d397.pdf (10.08.2017).

Borio, C. (2012). The financial cycle and macroeconomics: What have we learnt? BIS Working Papers, No: 395, Basel, 1-32.

Cerrato, M., Choudhry, M., Crosby, J. and Olukuru, J. (2012). Why do UK banks securitize?, DOI: 10.2139/ssrn.2051379, 1-36.

Choi, Y. J. (2013). The Global Financial Crisis Revisited: Competition and Regulation, Global Economic Review: Perspectives on East Asian Economies and Industries, 42:4, 362-381.

Chwieroth, J. (2011). The crisis in global finance: political economy perspectives on international financial regulatory change. In: Center for International Affairs, (corp. ed.) Beyond national boundaries: building a world without walls. Academy of Korean Studies Press, Seoul.

Cihak, M., Demirgüç-Kunt, A., Feyen, E. and Levine, R. (2012). Benchmarking Financial Systems Around the World, World Bank Policy Research Working Paper, 6175, World Bank, Washington, D.C.

Claessens, S. and Kodres, L. (2014). The Regulatory Responses to the Global Financial Crisis: Some Uncomfortable Questions, IMF Working Paper: WP/14/46, 1-39.

Cohen, B.H. (2013). How have banks adjusted to higher capital requirements?, BIS Quarterly Review, September 2013, 25-41.

Cull, R and Martínez-Pería, M. (2013). Bank ownership and lending patterns during the 2008-2009 financial crisis: evidence from Latin America and Eastern Europe, Journal of Banking \& Finance, vol 37, no 12, pp 4861-78.

Davis, K. (2009). Financial Regulation after the Global Financial Crisis, The Australian Economic Review, 42/4, 453-456.

Deloitte. (2015). New strategies in a changing world of bank regulation, https://www2.deloitte.com/content/dam/Deloitte/es/Documents/servicios-financieros/Deloitte_ES_Servicios_Fianncieros_new-strategieschanging-world-of-bank-regulation.pdf, Deloitte Banking Union, Frankfurt.

Duffie, D. (2016). Financial regulatory reform after the crisis: an assessment, ECB Forum on Central Banking, 27-29 June 2016, 1-45.

Edgar, R.J. (2009). The Future of Financial Regulation: Lessons from the Global Financial Crisis, The Australian Economic Review, Vol. 42, No. 4, 470-476.

Ennis, S., Kirkpatrick, G., Lloyd, G. and Lumpkin, S. (2009). The Financial Crisis: Reform and Exit Strategies, OECD Publications, New York.

Erturk, I. (2016). Financialization, bank business models and the limits of post-crisis bank regulation, Journal of Banking Regulation, Vol. 17, 1/2, 60-72.

ESRB. (2014). Is Europe Overbanked?, European Systemic Risk Board Advisory Scientific Committee, ASC Report, No: 4.

Finance-Watch. (2017). Money Market Funds Key Issues, http://www.finance-watch.org/our-work/dossiers?fid=153\&keyissues=1 (12.08.2017).

Financial Stability Board. (2011). Shadow Banking: Strengthening Oversight and Regulation, Recommendations of the Financial Stability Board, October, 1-39.

Financial Stability Board. (2017). Implementation and effects of the G20 financial regulatory reforms, Report of the Financial Stability Board to G20 Leaders, July, Basel.

Friedman, J. and Kraus, W. (2011). Engineering the Financial Crisis: Systemic Risk and the Failure of Regulation, University of Pennsylvania Press, Pennsylvania.

Gilad, S. (2015). Political Pressures, Organizational Identity, and Attention to Tasks: Illustrations From Pre-Crisis Financial Regulation, Public Administration, Vol. 93, Issue 3, 593-608.

Giordana, G. A. and Schumacher, I. (2017). An Empirical Study on the Impact of Basel III Standards on Banks' Default Risk: The Case of Luxembourg, Journal of Risk and Financial Management, Vol. 10, 1-21.

Giordana, G. A. and Schumacher, I. (2013). Bank liquidity risk and monetary policy: Empirical evidence on the impact of Basel III liquidity standards, International Review of Applied Economics, Vol.27, 633-655. 
Glinavos, I. (2014). Redefining the Market-State Relationship Responses to the financial crisis and the future of regulation, Routledge, New York. Greenman, P.S. and Osborn, J.W. (2012). Regulation of Over-the-Counter Derivatives Under the Dodd-Frank Wall Street Reform and Consumer Protection Act, Capital Markets, https://www.skadden.com/(15.08.2017).

Gudmundsson, B.R. (2015). Financialisation and Financial Crisis in Iceland, Working Paper, No. 55/2015, Institute for International Political Economy, Berlin.

Harari, D. (2017). Household debt: statistics and impact on economy, House of Commons Library, Briefing Paper, Number 7584, 1-23.

Hessou, H. and Lai, V.S. (2017). Basel III capital buffer requirements and credit union prudential regulation, Journal of Financial Stability, DOI: http://dx.doi.org/doi:10.1016/j.jfs.2017.05.002, 1-51.

International Monetary Fund. (2017). Global Financial Stability Report. Is Growth at Risk? Washington D.C. October.

Kim,T., Koo, B. and Park, M. (2012). Role of financial regulation and innovation in the financial crisis, Journal of Financial Stability, DOI: http://dx.doi.org/10.1016/j.jfs.2012.07.002, 1-11.

Krainer, R.E. (2012). Regulating Wall Street: The Dodd-Frank Act and the New Architecture of Global Finance, a review, Journal of Financial Stability, Vol: 8, 121-133.

Kroszner, R.S. (2010). Making Markets More Robust, (in) Kroszner, R.S., Shiller, R.J. and Friedman, B.M., Reforming U.S. Financial Markets, The MIT Press, Massachusetts, 58-83.

Lapteacru, I. (2016). On the consistency of the -score to measure the bank risk, LAREFI Universite de Bordeaux, Working Paper, N²016-05, 1-36.

Lothian, T. (2012). Beyond macroprudential regulation: Three ways of thinking about financial crisis, regulation and reform, Global Policy, doi: 10.1111/j.1758-5899.2011.00167.x, 1-11.

Mavroudeas, S.D. and Papadatos, D. (2012). Financial regulation in the light of the current global economic crisis, International Critical Thought, $2 / 4,486-499$

Merrouche, O. and Nier, E. (2010). What Caused the Global Financial Crisis?-Evidence on the Drivers of Financial Imbalances 1999-2007, Working Paper: WP/10/265, IMF Working Papers, Washington, DC.

Nolle, D.E. (2012). Global financial system reform: the Dodd\#Frank Act and the G20 agenda, Journal of Financial Economic Policy, Vol. 4:2, 160197.

Pirrong, R.E. (2011). Commodity Market Regulation After Financial Crisis: A Comparative Approach, Economic Affairs, Vol: 31, 41-46.

Rossi, S., Borroni, M., Lippi, M. and Piva, M. (2018). Determinants of Bank Profitability in the Euro Area: What Has Changed During the Recent Financial Crisis?, International Business Research, Vol. 11, No. 5, 18-27.

Quaglia, L. (2013). Financial regulation and supervision in the European Union after the crisis, Journal of Economic Policy Reform, Vol: 16:1, 1730

Rubio, M. and Carrasco-Gallego, J.A. (2016). The New Financial Regulation in Basel III and Monetary Policy: A Macroprudential Approach, Journal of Financial Stability, DOI: http://dx.doi.org/doi:10.1016/j.jfs.2016.07.012, 1-32.

Sanders, B.C. (2013). Financial Regulatory Reform: Benefits, Costs, and Challenges of the Dodd-Frank Act, Nova Science Publishers, New York.

Schultz, P.H. (2014). Perspectives on Dodd-Frank and Finance, MIT Press, Massachusetts.

Scott, H.S. (2010). Systemic Risk Reduction, (in) Kroszner, R.S., Shiller, R.J. and Friedman, B.M. (Eds.) Reforming U.S. Financial Markets, The MIT Press, Massachusetts, 110-117.

Seibt, C.H. and Schwarz, S. (2011). European financial market regulation in the wake of the financial crisis: a functional approach, China-EU Law Journal, Vol.1, 95-118.

Shaikh, A. (2011). The first great depression of the 21st century, Socialist Register, Vol. 7, 44-63.

Shiller, R.J. (2010). Democratizing and Humanizing Finance , (in) Kroszner, R.S., Shiller, R.J. and Friedman, B.M. (Eds.) Reforming U.S. Financial Markets, The MIT Press, Massachusetts, 1-49.

Sironi, A. (2018). The Evolution of Banking Regulation Since the Financial Crisis: A Critical Assessment (November 2018). BAFFI CAREFIN Centre Research Paper, No. 2018-103, 1-60, Available at SSRN: https://ssrn.com/abstract=3304672

Stiglitz, J. E. (2010). The Stiglitz Report: Reforming the International Monetary and Financial Systems in the Wake of the Global Crisis, The New Press, New York. 
Stöhr, A. (2015). Approaches to financial regulation in view of the crisis, Journal of Financial Regulation and Compliance, Vol. 23 Issue: 1, 73-83. Stremmel, H. and Zsamboki, B. (2015). The relationship between structural and cyclical features of the EU financial sector, ECB Working Paper No: $1812,1-32$.

Teixeira, J.C.A., Silva, J.F., Fernandes, A.V. and Alves, A.C. (2014). Banks' capital, regulation and the financial crisis, North American Journal of Economics and Finance, Vol: 28, 1-26.

Tian, W. (2017). Commercial Banking Risk Management: Regulation in the Wake of the Financial Crisis, Palgrave Macmillan, New York.

United Nations. (2015). Financial Regulatory Reform after the Crisis: Making the international financial architecture work for development, Report of United Nations Conference on Trade and Development, 2015, Geneva.

Vazquez, F. and Federico, P. (2012). Bank Funding Structures and Risk: Evidence from the Global Financial Crisis, IMF Working Paper, WP/12/29, $1-22$.

Werner, R.A. (2014). Can banks individually create money out of nothing? - The theories and the empirical evidence, International Review of Financial Analysis, Vol. 36, 1-19

World Bank. (2006). Measuring banking sector development, Financial Sector Indicators Note: 1, World Bank Financial Sector Operations and Policy Office, Washington DC. 